\title{
THE SOCIAL CONSTRUCTION OF ENTREPRENEURSHIP: HOW ENTREPRENEURSHIP EDUCATION INFLUENCES STUDENTS' PERCEPTIONS
}

\author{
Ksenija Vuković ${ }^{1 *}$, Tamara Šmaguc ${ }^{2}$, Kristina Detelj ${ }^{3}$ \\ ${ }^{1}$ Prof. Dr., University of Zagreb, Faculty of Organization and Informatics, CROATIA \\ ksenija.vukovic@foi.unizg.hr \\ ${ }^{2}$ Senior Asst. Dr., University of Zagreb, Faculty of Organization and Informatics, CROATIA \\ tamara.smaguc@foi.unizg.hr \\ ${ }^{3}$ Asst. Prof. Dr., University of Zagreb, Faculty of Organization and Informatics, CROATIA \\ kristina.detelj@foi.unizg.hr \\ ${ }^{*}$ Corresponding author
}

\begin{abstract}
The aim of this paper is to examine how students in Croatia construct the concept of entrepreneur and what is the role of entrepreneurship education in creating students' perceptions. The paradigmatic framework of the research is social constructivism, and in the methodological sense the study is based on a qualitative methodology. Primary data was collected by conducting semi-structured interviews with 25 students from different faculties in the Republic of Croatia. Research findings show that our students perceive a typical entrepreneur as a person with excellent communication and listening skills, who is also very proactive, flexible and people-oriented, and has a strong desire to achieve and dedication to work. Students with less strong entrepreneurial education believe that entrepreneurs are driven primarily by material gain, senior students with strong entrepreneurial education or experience perceive the heterogeneity of goals and interests of entrepreneurs through entrepreneurship as a lifestyle and self-actualization. The image of entrepreneurs and entrepreneurship among students involved in some form of entrepreneurship education is predominantly positive, sometimes reinforced by feelings of admiration, which differs significantly from the view of entrepreneurship within the wider community. Such results are optimistic as they confirm that quality entrepreneurship education could influence the gradual reshaping of social and cultural norms in a way that they would support the strengthening of entrepreneurial capacity in Croatia. In addition to the new empirical knowledge, the main contribution of the research includes a set of recommendations for practice directed to creators of entrepreneurship education programs in Croatia and other comparable countries.
\end{abstract}

Keywords: social construction, entrepreneurs, entrepreneurial education, qualitative approach

\section{INTRODUCTION}

Entrepreneurial competence is recognized by EU as one of the eight key competences for lifelong learning, which means acting in accordance with opportunity and ideas, and the ability to transform them into value for others. In 2010, the National Strategy for Entrepreneurial Learning 2010-2014 was adopted in Croatia, with two primary objectives - sensitive the public about entrepreneurship, develop a positive attitude towards 
lifelong learning for entrepreneurship, and introduce learning and training for entrepreneurship as key competences in all forms, types and levels of formal, non-formal and informal education and learning. Other strategies (Ministry of Economy, Ministry of Science and Education) have taken similar approach towards entrepreneurial competences so in the curricular reform parts of this approach have been implemented even on the primary and secondary schooling level in the last decade (School Education Gateway, 2015).

Whether entrepreneurship education in the Croatian education system has influenced the perceptions of entrepreneur and attitudes towards an entrepreneurial career among Croatian students is still an open question. With this question in focus, we conducted the research aimed at examining how students involved in higher education in Croatia construct the concept of an entrepreneur. In the study we examined the role of entrepreneurship education in creating student views of the entrepreneur as an individual and entrepreneurship as a process, and explored students' perceptions of some components of the entrepreneurial ecosystem in Croatia. The paradigmatic framework of the research is social constructivism (Guba and Lincoln, 1994), and in the methodological sense the study is based on a qualitative methodology (Patton, 2002). Primary data was collected by conducting semi-structured interviews with 25 students from different faculties in the Republic of Croatia. In addition to the new empirical knowledge, the main contribution of our research includes a set of recommendations for practice directed to creators of entrepreneurship education programs in Croatia and other comparable countries.

After a theoretical overview of the role of entrepreneurship education, in the second part of the paper we present the macro-context of research through a description of the basic characteristics of entrepreneurial activity and entrepreneurship education in the Republic of Croatia. The third part of the paper refers to the description of the research methodology after which the research findings are elaborated. Conclusions and recommendations are given at the end of the paper.

\section{THE ROLE OF ENTREPRENEURSHIP EDUCATION}

Entrepreneurship education can be defined as "the process of providing individuals with the concepts and skills to recognize opportunities that others have overlooked and to have the insight and self-esteem to act where others have hesitated" (Mclntyre and Roche, 1999, p. 33, as cited in Zhang, Duysters and Cloodt, 2013, p. 624). By focusing on knowledge, skills and attitudes, entrepreneurship education prepares individuals for entrepreneurial behaviour by enabling them to be responsible and achieve their goals in a business context. The knowledge gained through the participation of individuals in entrepreneurship education programs includes a broader understanding of entrepreneurship as a process and the role that the entrepreneur assumes. Entrepreneurial skills concern the capacity of an individual to realize their business ideas, and include soft entrepreneurial skills such as social skills and hard entrepreneurial skills such as the skill of preparing a business plan and managing a company's finance. Finally, an important task of entrepreneurship education is the (re)shaping of attitudes towards entrepreneurship. The aim is to develop an entrepreneurial mindset of individuals who will be ready to implement a business idea and take responsibility for their own career, learning, and professional and personal development (European Commission, 2012).

Liñán (2004) makes a distinction between several forms of entrepreneurial education: (1) entrepreneurial awarness education whose goal is to encourage entrepreneurial behaviour and provide a broader perspective and does not necessarily refer to encouraging an individual to start their own business but to make more proactive career decisions; (2) education for start-up that enables the acquisition of practical knowledge and skills for starting a business and is aimed at people who have an entrepreneurial intention; (3) education for entrepreneurial dynamism which is aimed at entrepreneurs who have moved from the startup phase to the growth phase, and its goal is to provide participants the knowledge needed to manage sustainable growth and development of the company and (4) continuing education for entrepreneur which belongs to the category of adult education programs aimed at strengthening the existing entrepreneurial abilities of an entrepreneur (Liñán, 2004, as cited in Weber, 2012, p. 14-15).

According to the European Commission (2012), entrepreneurship education should address at least one of the following components:

- "foster those personal attitudes and skills that form the basis of an entrepreneurial mindset and behaviour (creativity, risk propensity, self-confidence, independence, etc.)

- $\quad$ raise awareness of students about self-employment and entrepreneurship as possible career options

- use practice-based methods, where students are involved in project work and/or in activities outside the classroom (linking them with the business world or with the local community) 
provide basic business skills for self-employment or self-management, and knowledge of how to start and develop a commercial or social venture successfully" (European Commission, 2012, p. 44).

The role of entrepreneurship education has so far been the subject of a large number of empirical studies. In a recent systematic review of this topic in higher education, Nabi et al. (2017) conducted a meta-analysis of 159 articles published in the period from 2004 to 2016. As they conclude, most research finds a positive relationship between entrepreneurship education programs and subjective (e.g., personal change) or objective (e.g., business start-up activity) impact indicators. Also, for entrepreneurial education, a large number of studies have found a positive impact on student start-up intentions (Nabi et al., 2017), which is moderated by cultural values in society. Namely, according to Bae et al. (2014) in high collectivist societies the impact of entrepreneurial education on the start-up intentions of education program participants is significantly weaker than in individual cultures. In addition to cultural norms, the impact of entrepreneurship education on entrepreneurial outcomes in certain cases can be moderated by gender (e.g., Joensuu et al., 2013; Shinnar, Hsu and Powell, 2014) and context-specific patterns (e.g., Piperopoulos and Dimov, 2015). Thus, for example, Joensuu et al. (2013) find that male gender is associated with a higher level of initial entrepreneurial intentions (prior to involvement in entrepreneurial education), and has a positive impact on entrepreneurial intentions, as opposed to female gender where this is not the case. Shinnar, Hsu and Powell (2014) conclude that entrepreneurial education influences the growth of students' entrepreneurial selfefficacy. But this growth is statistically significant only for male students. An interesting study was also conducted by Piperopoulos and Dimov (2015) who concluded that higher self-efficacy is associated with lower entrepreneurial intentions in the theoretically oriented courses, and higher entrepreneurial intentions in the practically oriented courses.

While the approach of quantitative analyses of the impact of entrepreneurship education on different types of entrepreneurial outcomes is saturated, few studies explore this topic from the perspective of the interpretive research paradigm (Burrell and Morgan, 1979). Understanding the issue requires in-depth examination of contextual factors that could influence the perceptions and experiences of program participants and program outcomes. Therefore, the quantitative approach to the study of cause-and-effect relationships should be complemented by qualitative studies (Vuković, Šmaguc and Vuković, 2016). Qualitative research into the role of entrepreneurship education programs from the categories of different actors involved (such as educators, students, alumni and entrepreneurs) will facilitate the understanding of the needs of participants in such programs and will create richer implications that take into account national, temporal and other contexts. With this in mind, we created a qualitative study aimed at examining the perspective of students involved in entrepreneurship education in Croatia. Accordingly, in order to bring the macro-context of the research closer to the readers, below we present data on entrepreneurial activity and entrepreneurship education in Croatia.

\section{MACRO-CONTEXT OF THE RESEARCH: ENTREPRENEURIAL ACTIVITY AND ENTREPRENEURSHIP EDUCATION IN CROATIA}

The structure of the Croatian economy is extremely stable. Small and medium-sized enterprises (SMEs) comprise $99.7 \%$ in the number of enterprises. In 2019 SMEs employed almost three quarters $(72.2 \%)$ of all employees in Croatia, the sector accounted for $60.3 \%$ of total income and in the total exports in 2019 , the SMEs participate with a share of $52.9 \%$. Micro enterprises are the least competitive and productive, and with lesser extent of internalization within the SMEs, but they are showing continuous improvement of business results, though not enough for strengthening their international competitiveness (Alpeza et al., 2020).

Population of Croatia comprises $51.7 \%$ of women and $48.3 \%$ of men (CBS, 2021). But women are generally more often enrolled in higher education institutions (HEls). In the academic year 2019/2020 in Croatia, women account for $57.2 \%$, and men are $42.8 \%$, except in technical sciences. The difference increases when it comes to postgraduate specialist studies $(65.1 \%$ vs. $34.9 \%)$ and in doctoral studies there are $54.7 \%$ of women enrolled. Regarding employment in 2019 , women accounted for $47.6 \%$ of the total number, with the share of women's wages in males of $86.7 \%$. Despite the overwhelming share of women in education, the share of women in employment is lower than the share of men, and is further significantly reduced in the share of company owners. This disparity is the result of unequal participation of women and men in family life obligations (child and older care), which is a cultural problem whose solution requires interventions to the education system (Alpeza et al., 2020).

According to the Startupblink's latest Startup Ecosystem Rankings 2020, Croatia is 39th best location for startups in the world (out of 202), improved by 11 places in relation to 2019. The report recommends to position Zagreb as a regional startup centre, while it should offer the other cities help and support for the 
improvement of the startup environment. This would reduce the emigration of young and talented entrepreneurs who often initiate their startups in London or Vienna. Public sector should provide support to private initiatives, but also to be more involved in the development of the startup ecosystem. According to the global competitiveness index, Croatia was in the 63th out of 141 countries, rank was raised YoY by 5 places. Among the worst rated components are those that make up the innovation ecosystem: business dynamics (administrative requirements and entrepreneurial culture which is extremely poorly rated); aversion to entrepreneurial risk, and companies are not prone to disruptive ideas; research and development are a bit better rated, but difficult to commercialize; the worst ratings are for the diversity of the workforce (134th place), the development of clusters (132nd) and cooperation stakeholders from different areas (132nd place) (Alpeza et al., 2020).

Entrepreneurial education in Croatia was scarcely present in the educational programs until mid-2000s. Even then, the most of the courses tackling entrepreneurship were taught only in economy high school programs and in the faculties of business and economic within HEls. There are a total of 224 university and polytechnic studies in the scientific field of social sciences, fields of economics in Croatia, of which 25 are study programs related to entrepreneurship. Out of 25 entrepreneurship study programs, 4 are undergraduate university studies, 5 are graduate university studies, one is postgraduate university (doctoral) study program, 4 are postgraduate specialist studies, 7 are undergraduate professional studies and 4 are specialist graduate professional studies (Mozvag, 2021). In recent years other technical and science study programs also include courses dealing with entrepreneurship and economics in their study programs (e.g. Faculty of Engineering and Computing, Agricultural Faculty, Textile Technology Faculty etc.) but this is usually on the introductory level. In secondary education, entrepreneurship has been recognized as a set of knowledge and skills in vocational schools, through subjects Entrepreneurship and Training Firm/Vocational Practice for many years.

In the non-formal education there are also different programs that teach entrepreneurial skillset. One of the newest ones is the program Entrepreneurial academy from the Varaždin Public Open School which uses experienced entrepreneurs to teach the interested parties, which is free for the participants (POU Varaždin, 2021). Also, from the time of Croatian candidacy and entering the EU, there are lots of European funds and programmes that aim to improve the human capital (e.g. European Social Fund, Erasmus+ and similar) which allows local authorities to organize different kinds of courses or short-term workshops for disseminating knowledge and developing entrepreneurial skills. These are temporary and mainly free for participants.

\section{RESEARCH METHODOLOGY}

In line with the paradigmatic framework of the study and its objectives, the methodological approach of the research is based on a qualitative inquiry. Primary data was collected by conducting semi-structured interviews with 25 respondents. A semi-structured interview is an appropriate data collection technique for this research given that in this type of interview the researcher has a pre-prepared interview guide that contains questions to be asked to the respondent. At the same time, the form of the interview is not strict since the researcher and the respondent follow the logic of the conversation and the respondent answers the questions freely and spontaneously (Tkalac Verčič, Sinčić Ćorić and Pološki Vokić, 2014).

Two types of purposeful sampling were used in the design of the sample of interview participants - criterion sampling and snowball sampling (Patton, 2002). Data collection was realized in the period from June to July 2021. The participants of the interview were students who during the research studied in one of a total of 16 study programs (undergraduate, graduate, professional, specialist and doctoral study program) conducted at 12 different faculties throughout the Republic of Croatia (in Varaždin, Zagreb, Čakovec, Osijek, Rijeka, Pula and Križevci). The criterion for participation in the research was the involvement of participants in some form of entrepreneurship education as part of university education. Respondents were also selected in a way to ensure the participation of students from as many different faculties and study programs as possible. The interview was preceded by informing the respondents about the purpose of the study and the manner of conducting the research, which was performed by phone or e-mail. A total of 15 women and 10 men participated in the interview. The average duration of one interview was about 60 minutes. All interviews were conducted online, using applications such as Zoom, Big Blue Button or Skype.

With the prior consent of the respondents, each interview was recorded using an audio device, which enabled the production of credible transcripts. The analysis of empirical data was performed using coding techniques, manually, ie. without computer software support. An average of 4 hours was spent on open coding and focused coding (Charmaz, 2006) of one interview. The last step in the analysis concerned the implementation of axial coding (Charmaz, 2006; Corbin and Strauss, 2015). Ethical aspects of the research 
were taken into account during data collection and data manipulation, and during the writing of the results report. Accordingly, all names of respondents in this paper have been replaced by pseudonyms.

\section{RESEARCH RESULTS}

Immersed in entrepreneurship education without previous experience in entrepreneurship and weak ideas about entrepreneurship as a profession, the educational choices of our students were directed by practical motives (geographical proximity of the faculty, faculty of economics as a natural continuation of secondary economic education, a wide range of jobs that a person can work after graduation). However, there is a minority for whom the choice of entrepreneurship education is guided by intriguing incentives for future selfrealization in entrepreneurship, mainly instilled through the process of intra-parental transmission of entrepreneurial aspirations (Bloeman-Bekx et al., 2019) (growing up with an entrepreneur's parent, entrepreneurship in the immediate family):

It just came to me... When I would analyze [I chose entrepreneurship education] because I grew up in an environment where my father was an entrepreneur, and I watched him, and I had a feeling I wanted to try myself in entrepreneurial waters... (Kristina)

Our students perceive a typical entrepreneur as a person with excellent communication and listening skills, who is also very proactive, flexible and people-oriented, and has a strong desire to achieve and dedication to work. A few of them incorporate his demographic characteristics into the image of a typical entrepreneur, identifying him with a middle-aged man with a richer professional experience. When it comes to the dominant drivers of entrepreneurial activity, students' attitudes are not unique. While some see them exclusively in financial breakthroughs, others are aware of the heterogeneity of entrepreneurial goals (Kuratko, Hornsby and Naffziger, 1997), highlighting the pursuit of independence in business and the desire for self-realization as primary entrepreneurial stimuli. Such a divergence in attitudes may be somewhat related to the scope and quality of entrepreneurial education in which the student is involved.

When it comes to the primary association of students to entrepreneurship, it is mainly formed under the influence of the media and exposure to entrepreneurial examples mentioned in class (Mate Rimac, Emil Tedeschi, Bill Gates, Elon Musk). Impressions related to role models in entrepreneurship, however, are of a different origin. They can spring from closeness and emotion (successful entrepreneur - family member) or they are the product of feelings of admiration for a specific young entrepreneur or entrepreneurs within an intriguing niche. The latter is nicely illustrated by the statement of student Ines, who recognizes the entrepreneurial role model in a woman - a successful Croatian designer:

[My role model in entrepreneurship is] Katarina Baban, I regularly follow her website, her way of creating dresses, she graduated from an acting academy and then switched to design, she changed the industry, she managed to fit everything she does together, she networked well... other fashion icons wear her cuts, she manages to leave a dose of self-promotion... .so she is etched in my memory, especially because she is a woman entrepreneur. (Ines)

Obviously, the image of entrepreneurs among students involved in some form of entrepreneurship education is predominantly positive, sometimes reinforced by feelings of admiration, which differs significantly from the view of entrepreneurship within the wider community (Šmaguc, 2019). As students' perceptions reveal to us, in Croatian society, entrepreneurship is often intoned negatively, especially among the older population. The negative connotations that students witness describe attributes such as the exploiter of the worker, the profiteer who lives well with little effort, the person who is prone to breaking the law. According to Marko, this is a consequence of the negative aspects of the privatization process that younger generations have not witnessed, which is why, according to a large number of respondents, the image of entrepreneurs in society has been gradually transformed in recent years:

At the faculty, [entrepreneurs] are highly valued because it is known how big their responsibility is, it is known that without them there is no added value, and most students already have their family farm and positive connotations towards entrepreneurship. My friends are entrepreneurs, they own IT companies ... Before, the word entrepreneur in the Republic of Croatia was negative, but now it is no longer so... (Alen)

Within their milieu, students attribute the role of a potential entrepreneur to people who are extroverted and communicative and stand out in the group, but are at the same time reliable, diligent and strongly motivated to engage in extracurricular activities. These are young people who have some experience in entrepreneurship within the family and let themselves know about their entrepreneurial aspirations, or their entrepreneurial potential is recognized in the high level of entrepreneurship in college (involvement in various project activities, leading teams and student associations, etc.): 
One female student [from the group could be an entrepreneur] - she always stands up for herself, she is always one step ahead of others, she is a bit strenuous... She always asks, everyone knows her, it stands out ... banks are more inclined to give money to whoever develops the idea exactly, and she is like that... (Igor)

Since this is an important and topical topic, our interviews also included examining students' awareness of the issue of gender imbalance in entrepreneurship. Student assessments of the representation of content related to women's entrepreneurship and gender issues in entrepreneurship in the curricula of entrepreneurship programs vary significantly. While some students have not touched on these topics, others deal with them at least in the form of seminar papers. One part of the research participants is satisfied with the representation of subject content in the faculty program (topics are covered in several subjects) and leave the impression (at least to some extent) of familiarity with the topic of gender differences in entrepreneurship. Topics mentioned by knowledgeable students include the issue of less statistical representation of women in entrepreneurship, barriers for women entrepreneurs and the specifics of entrepreneurial venture led by women.

Students recognize at least some of the key players in the entrepreneurial ecosystem, mostly local organizations that cooperate with the faculty the student attends (for example Varaždin Technology Park) and institutions based on the profile of the study the student attends (for example, Agricultural Management students mention associations in the field of agriculture). At the same time, student assessments regarding the possibility of equal access to all institutions are heterogeneous. Some respondents are of the opinion that potential and existing entrepreneurs have equal access to institutions, while their lack of familiarity with the offer of services limits their use. The second group of respondents is of the opinion that access to institutions strongly determines the involvement of entrepreneurs in the political field, which facilitates access for some, limiting options for other entrepreneurs. These results are in line with the findings of Šmaguc and Vuković (2017) who explored the perspective of ICT entrepreneurs in Croatia, suggesting a lack of trust of the entrepreneurial population in institutions.

Regarding the social security of students, given that the groups are homogeneous in many characteristics (ethnicity, religion), there is no feeling of undesirableness, discrimination or exclusion:

Various gatherings and various associations were organized at the faculty. I wasn't part of it, but everyone was invited. Our college was inclusive, trying to include people with various disabilities, there was no discrimination. (Eva)

One respondent, a female, stated that in college she initially did not find understanding with male colleagues, they felt she could not be better than them since she was female, they did not accept her opinion. However, the professors treated her the same as the male students.

Students' perceptions regarding the possibility of one day becoming entrepreneurs are heterogeneous. In accordance with existing findings (Johansen, 2013; Arshad, 2018; Garaika and Margahana, 2019), almost all students point out that entrepreneurial education over time has had a positive effect on their self-confidence in a career in entrepreneurship. However, there are also those students who with the increase in knowledge about entrepreneurship (especially the obstacles faced by the entrepreneur) show increased fear of failure in entrepreneurship, which reduces their intention to one day truly become entrepreneurs (Oosterbeek, 2010). Students who express entrepreneurial aspirations generally see themselves as leaders of a smaller company in a specific niche that is interesting to them. They expect financial and other support from their immediate family, as well as emotional support from friends, which suggests the importance of "strong" social ties (Putnam, 1995, 2000) in the realization of an individual's entrepreneurial potential:

As for family members I think they would even give me financial support, my mother would give me part of the savings, friends [would support me but would be] more passive, but I don't expect anything else from them either. (Alen)

\section{CONCLUSION AND RECOMMENDATIONS}

Our empirical results suggest that entrepreneurial education is generally in a relation with student favourable perceptions of entrepreneurs and entrepreneurship. In contrast to the still unfavourable picture of entrepreneurship in the general population reported by GEM results for Croatia (Singer et al., 2021), thanks to education, the younger generations have a different perception of the role of entrepreneurs. The importance of education in creating a good image of entrepreneurs is confirmed by certain differences in the perceptions of students of different levels of study (graduate students have more knowledge and are more aware of the tasks and goals of entrepreneurs and entrepreneurship compared to undergraduate students). 
Such results are optimistic as they confirm that quality entrepreneurship education could influence the gradual reshaping of social and cultural norms in a way that they would support the strengthening of entrepreneurial capacity in Croatia (Singer et al., 2021).

In addition to the fact that, according to students 'perceptions, involvement in entrepreneurship education had a positive effect on students' entrepreneurial self-efficacy, the supporting context for the participants are also community built on "strong" social ties (Putnam, 1995, 2000). Family and close friends are an environment from which they expect financial or at least emotional support - if one day they decide to try their hand at an entrepreneurial career.

In accordance with the results of Šmaguc and Vuković (2017) and Šmaguc (2019), the areas in which there is certainly room for improvement in Croatia are government policies and government programs aimed at entrepreneurship. In addition to entrepreneurs (Šmaguc and Vuković, 2017; Šmaguc, 2019), students themselves assess this component of the entrepreneurial ecosystem as unfavourable, both due to insufficient information of potential program users and due to potential illegal benefits associated with access to such programs. In this sense, in addition to improving the quality of the entrepreneurial ecosystem in Croatia, it is necessary to work on building the trust of students - potential entrepreneurs in Croatian institutions that are in the function of supporting entrepreneurship.

The results of our research point to a number of recommendations for creators of entrepreneurship education programs in Croatia and other comparable countries. The most important recommendations include the following:

- Entrepreneurship education should be more embedded in secondary education as students mention the transition from high school to college as a moment of strong change in the image of entrepreneurship and the entrepreneur

- The role of the media in recognizing entrepreneurship and the image of who is an entrepreneur is huge it should be used - the media according to students' perceptions do not participate sufficiently in the promotion of entrepreneurship

- It should be borne in mind that entrepreneurial education has a very positive effect on creating an image of the entrepreneur and strengthening self-confidence, but in some students potentially adversely affects self-confidence because of strengthening their fears about the dangers of entrepreneurial career (fear of failure, etc.)

- It is necessary to work on reducing the fear of failure because it is very pronounced among students, including those who are extroverted

- Creating a better entrepreneurial ecosystem (supportive environment, reduction of administrative barriers, reduction of fear of failure, safer macroeconomic business conditions) according to students' attitudes would increase their self-confidence to engage in entrepreneurship

- during the studies it is necessary to point out the possibilities of additional preparation for entrepreneurship through education and mentoring programs, especially those that are free

- Entrepreneurs - guest lectures are extremely important for students, but it is necessary to think when choosing a guest - the strongest impression is left by those with whom students easily identify

- Students with less strong entrepreneurial education believe that entrepreneurs are driven primarily by material gain, senior students with strong entrepreneurial education (and/or experience) perceive heterogeneity of goals and interests of entrepreneurs - it is necessary to bring all students closer to the idea of heterogeneity of motives for entrepreneurial activity.

This research has several limitations. Since this is a qualitative study, the results refer to a specific research context and should not be statistically generalized to other contexts (Smith, 2018). Despite the large number of interviewees, it would be good for future similar research to include participants from all faculties, including those from the southern parts of Croatia who are not represented in this study (for example Split and Dubrovnik). Finally, the fact that the research indicates only one perspective that of the students should be taken into account. Therefore, future similar studies should examine the same research objectives from the view of other groups of respondents - entrepreneurship educators, alumni, entrepreneurs and stakeholders from the Croatian institutional milieu. Comparing the views of different categories of stakeholders would contribute to a more comprehensive understanding of the phenomenon and would enrich the implications for the creation and improvement of entrepreneurship education programs in Croatia and other comparable countries. 


\section{REFERENCE LIST}

Alpeza M., Delić, A., Has, M., Koprivnjak, T., Mezulić Juric, P., Oberman, M., Perić, J., \& Šimić Banović. R. (2020). Izvješće o malim i srednjim poduzećima u Hrvatskoj - 2020. http://www.cepor.hr/wpcontent/uploads/2021/01/lzvjesce-2020-HR-web.pdf

Arshad, M., Farooq, O., \& Afzal, S. (2018). The role of entrepreneur-ship education in developing a passion for business. Global Business and Organizational Excellence, 38(1): 15-21. https://doi.org/10.1002/joe.21896

Bae, T. J., Qian, S., Miao, C., \& Fiet, J. O. (2014). The relationship between entrepreneurship education and entrepreneurial intentions: A meta-analytic review. Entrepreneurship Theory and Practice, 38(2): 217254. https://doi.org/10.1111/etap.12095

Bloemen-Bekx, M., Voordeckers, W., Remery, C., \& Schippers, J. (2019). Following in parental footsteps? The influence of gender and learning experiences on entrepreneurial intentions, International Small Business Journal, 37(6): 642-663. https://doi.org/10.1177/0266242619838936

Burrell, G., \& Morgan, G. (1979). Sociological Paradigms and Organisational Analysis: Elements of the Sociology of Corporate Life. Burlington: Ashgate Publishing Company.

CBS. (2021) Procjene Stanovništva. Croatian Bureau of Statistics. https://www.dzs.hr/hrv/publication/StatisticsInLine.htm

Charmaz, K. (2006). Constructing Grounded Theory: A Practical Guide Through Qualitative Analysis. London, Thousand Oaks, New Delhi: Sage Publications.

Corbin, J. M., \& Strauss, A. L. (2015). Basics of Qualitative Research: Techniques and Procedures for Developing Grounded Theory. 4th edition. Los Angeles, London, New Delhi: Sage Publications.

European Comission (2012). Effects and impact of entrepreneurship programmes in higher education. Brussels: Entrepreneurship Unit. Directorate-General for Enterprise and Industry, European Commission.

Garaika G., \& Margahana, H. (2019). Self-Efficacy, Self-Personality and Self Confidence on Entrepreneurial Intention: Study on Young Enterprises. Journal of Entrepreneurship Education, 22(1): 1-12.

Guba, E. G., \& Lincoln, Y. S. (1994). Competing Paradigms in Qualitative Research, in Denzin, N. K. \& Lincoln, S. Y. (eds) Handbook of qualitative research. Thousand Oaks: Sage Publications, pp. 105117.

Joensuu, S., Viljamaa, A., Varamaki, E., \& Tornikoski, E. (2013). Development of entrepreneurial intention in higher education and the effect of gender: A latent growth curve analysis. Education + Training, 55(8/9): 781-803. https://doi.org/10.1108/ET-06-2013-0084

Johansen, V. (2013). Entrepreneurship education and start-up activity: a gender perspective. International Journal of Gender and Entrepreneurship. 5(2): 216-231. https://doi.org/10.1108/17566261311328864

Kuratko, D.F., Hornsby, J.S., \& Naffziger, D.W. (1997). An examination of owner's goals in sustaining entrepreneurship. Journal of Small Business Management, 35(1): 24-33.

Mozvag. (2021). Preglednik studijskih programa. https://mozvag.srce.hr/preglednik/

Nabi, G., Liñán, F., Fayolle, A., Krueger, N., \& Walmsley, A. (2017). The impact of entrepreneurship education in higher education: a systematic review and research agenda. Academy of Management Learning \& Education,16: 277-299. https://doi.org/10.5465/amle.2015.0026

Oosterbeek, H., Van Praag, M., \& ljsselstein, A. (2010). The impact of entrepreneurship education on entrepreneurship skills and motivation. European Economic Review, 54(3): 442-454. https://doi.org/10.1016/i.euroecorev.2009.08.002

Patton, M. Q. (2002). Qualitative Research and Evaluation Methods. 3th edition. Thousand Oaks, London, New Delhi: Sage Publications.

Piperopoulos, P., \& Dimov, D. 2015. Burst bubbles or build steam? Entrepreneurship education, entrepreneurial self-efficacy, and entrepreneurial intentions. Journal of Small Business Management, 
53(4): 970-985. https://doi.org/10.1111/isbm.12116

POU Varaždin. (2021). Akademija za poduzetništvo. https://azp.hr/

Putnam, R. D. (1995). Bowling Alone: America's Declining Social Capital, Journal of Democracy, 6(1): 6578.

Putnam, R. D. (2000). Bowling Alone: The Collapse and Revival of American Community. New York, London, Toronto, Sydney: Simon \& Schuster Paperbacks.

School Education Gateway. (2015). Entrepreneurship education in Croatia. https://www.schooleducationgateway.eu/downloads/entrepreneurship/Croatia_151022.pdf

Singer, S., Šarlija, N., Pfeifer, S., \& Oberman Peterka, S. (2021). Što čini Hrvatsku (ne)poduzetničkom zemljom? GEM Hrvatska 2019-2020. Zagreb: CEPOR.

Shinnar, R. S., Hsu, D. K., \& Powell, B. C. (2014). Self-efficacy, entrepreneurial intentions, and gender: Assessing the impact of entrepreneurship education longitudinally. International Journal of Management Education, 12(3): 561-570. https://doi.org/10.1016/i.jme.2014.09.005

Smith, B. (2018). Generalizability in qualitative research: misunderstandings, opportunities and recommendations for the sport and exercise sciences, Qualitative Research in Sport, Exercise and Health, 10(1): 137-149. https://doi.org/10.1080/2159676X.2017.1393221

Šmaguc, T., \& Vuković, K. (2017). Institutional Field in the Republic of Croatia: Perspective of Entrepreneurs Pertaining to Computer Programming Activities, in Strahonja, V. \& Kirinić, V. (eds) Central European Conference on Information and Intelligent Systems. Varaždin: Faculty of Organization and Informatics, University of Zagreb, pp. 145-151.

Šmaguc, T. (2019). Prakse stjecanja poduzetničkoga legitimiteta u djelatnosti računalnoga programiranja. Doctoral thesis. Zagreb: Faculty of Economics, University of Zagreb.

Tkalac Verčič, A., Sinčić Ćorić, D., \& Pološki Vokić, N. (2014). Priručnik za metodologiju istraživanja u društvenim djelatnostima. 2nd edition. Zagreb: M.E.P. d.o.o.

Vuković, K., Šmaguc, T., \& Vuković, P. (2016). The Methodological Choices in Entrepreneurship Research: Comparison of Mathematics and Entrepreneurship Paradigm, in Tarhan, A. \& Kaya, V. M. (eds) Review of Socio-Economic Perspectives. Ankara: Sanat Kırtasiyecilik Reklamcılık Ltd. Şti., pp. 85-99.

Weber, R. (2012). Evaluating entrepreneurship education. Gabler Verlag, Springer Fachmedien Wiesbaden. DOI: https://doi.org/10.1007/978-3-8349-3654-7

Zhang, Y., Duysters, G., \& Cloodt, M. (2013). The role of entrepreneurship education as a predictor of university students'entrepreneurial intention. International Entrepreneurship and Management Journal, 10: 623-641. https://doi.org/10.1007/s11365-012-0246-z 